\title{
Modulation of Cellular MicroRNA by HIV-1 in Burkitt Lymphoma Cells-A Pathway to Promoting Oncogenesis
}

\author{
Beatrice Relebogile Ramorola (D), Taahira Goolam-Hoosen, Leonardo Alves de Souza Rios (D) \\ and Shaheen Mowla *(D) \\ Division of Haematology, Department of Pathology, Faculty of Health Sciences, University of Cape Town, \\ Observatory 7925, Cape Town 7700, South Africa; beatrice.ramorola@gmail.com (B.R.R.); \\ taahira.goolamhoosen@uct.ac.za (T.G.-H.); leonardo.rios@uct.ac.za (L.A.d.S.R.) \\ * Correspondence: shaheen.mowla@uct.ac.za
}

Citation: Ramorola, B.R.;

Goolam-Hoosen, T.; Alves de Souza Rios, L.; Mowla, S. Modulation of Cellular MicroRNA by HIV-1 in Burkitt Lymphoma Cells-A Pathway to Promoting Oncogenesis. Genes 2021, 12, 1302. https://doi.org/ 10.3390/genes12091302

Academic Editor: Deborah J. Good

Received: 13 July 2021

Accepted: 20 August 2021

Published: 24 August 2021

Publisher's Note: MDPI stays neutral with regard to jurisdictional claims in published maps and institutional affiliations.

Copyright: (c) 2021 by the authors. Licensee MDPI, Basel, Switzerland. This article is an open access article distributed under the terms and conditions of the Creative Commons Attribution (CC BY) license (https:/ / creativecommons.org/licenses/by/ $4.0 /)$.

\begin{abstract}
Viruses and viral components have been shown to manipulate the expression of host microRNAs (miRNAs) to their advantage, and in some cases to play essential roles in cancer pathogenesis. Burkitt lymphoma (BL), a highly aggressive B-cell derived cancer, is significantly over-represented among people infected with HIV. This study adds to accumulating evidence demonstrating that the virus plays a direct role in promoting oncogenesis. A custom miRNA PCR was used to identify 32 miRNAs that were differently expressed in Burkitt lymphoma cells exposed to HIV-1, with a majority of these being associated with oncogenic processes. Of those, hsa-miR-200c-3p, a miRNA that plays a crucial role in cancer cell migration, was found to be significantly downregulated in both the array and in single-tube validation assays. Using an in vitro transwell system we found that this downregulation correlated with significantly enhanced migration of BL cells exposed to HIV-1. Furthermore, the expression of the ZEB1 and ZEB2 transcription factors, which are promotors of tumour invasion and metastasis, and which are direct targets of hsa-miR-200c-3p, were found to be enhanced in these cells. This study therefore identifies novel miRNAs as role players in the development of HIV-associated BL, with one of these miRNAs, hsa-miR-200c-3p, being a candidate for further clinical studies as a potential biomarker for prognosis in patients with Burkitt lymphoma, who are HIV positive.
\end{abstract}

Keywords: MicroRNA; miR-200c; Burkitt lymphoma; HIV-1; non-Hodgkin lymphoma; ZEB

\section{Introduction}

MicroRNAs (miRNAs) are a class of small noncoding RNA molecules that play an essential role in gene regulation post-transcriptionally [1,2]. In their mature form, miRNAs are approximately 18-22 nucleotides long and are incorporated into the RNA-induced silencing complex (RISC) where they can act as guides, leading the complex to the $3^{\prime}$ - UTR region of messenger RNA (mRNA). Upon complementary binding to the target mRNA, it is either targeted for degradation or translation is inhibited [3,4]. miRNAs are critical for normal cellular function and what has emerged clearly in the last decade is that aberrant miRNA expression is associated with many diseases, including malignancies. This is likely a result of amplification and/or deletion of specific genomic regions, with the deregulated miRNA having either an oncogenic or tumour suppressor role, affecting one or several of the cancer hallmark events [5,6].

Non-Hodgkin lymphomas (NHLs) represent a heterogeneous group of malignancies, which originate from lymphoid haematopoietic tissue, with the majority being of B-cell origin [7]. Quite early on in the acquired immune deficiency syndrome (AIDS) epidemic, an association between NHLs and AIDS was established, leading to the current classification of several NHL subtypes as being associated with HIV infection [8]. This includes Burkitt lymphoma (BL), a highly aggressive B-cell NHL characterized by the genetic hallmark $c-M Y C$ rearrangement with the immunoglobulin gene loci, and $t(8 ; 14)(\mathrm{q} 24 ; \mathrm{q} 32)$ being 
the most frequently observed translocation [9-11]. BL is one of the most common NHLs affecting HIV-positive individuals, and in developing countries, which carry the highest HIV burden worldwide, patients typically present with late-stage disease requiring aggressive treatment $[12,13]$. Importantly, recent evidence has emerged in support of HIV and HIV-1 encoded proteins having direct oncogenic effects, particularly in the development of $\mathrm{BL}$, and therefore the pathobiology of HIV-associated cancers is unique and distinct from cancers of the same type that do not develop within an HIV-positive background [14-18]. This is likely to include alterations in miRNA expression. Oncogenic viruses such as the Epstein-Barr virus (EBV) and the Kaposi's sarcoma-associated herpesvirus (KSHV), both of which are closely associated with HIV infection and the development of lymphoproliferative diseases, have been shown to alter the expression of a wide array of cellular miRNAs, with roles linked to the oncogenic process [19]. Although several studies have described specific miRNA expression signatures for various cancers including BL, none have described how these signatures may differ in the presence of HIV. While B-cells are not host to the virus, there is strong evidence that HIV binds to B lymphocytes through interactions with cell surface receptors [20]. HIV could thus potentially modulate miRNA expression through alteration of signalling pathways, contributing to oncogenesis. Identifying these interactions is valuable since a growing number of reports suggest that miRNAs can be useful biomarkers for pathogenic conditions, and hold therapeutic potential as they are targetable [21].

In the current study, 32 miRNAs were identified to be significantly deregulated in Burkitt lymphoma cells exposed to HIV-1 virions, compared to control cells, using a custom designed miRNA microarray. miRNA target prediction and functional annotation studies identified a majority of these miRNAs and their targets to be associated with biological processes and pathways associated with cancer. Of particular interest was the downregulation of hsa-miR-200c-3p, a miRNA that has strong associations with cancer cell invasion and migration [22,23]. Indeed, BL cells exposed to HIV-1 displayed enhanced migratory abilities. Furthermore, protein expressions of the ZEB1 and ZEB2 transcription factors, which are targets of hsa-miR-200c-3p and play key roles in cancer cell migration and invasion, were significantly enhanced in these cells. This study therefore provides evidence to support a role for HIV-1 in modulating the expression of cellular miRNAs in Burkitt lymphoma patients who are HIV positive, and that this contributes towards the cancer phenotype.

\section{Materials and Methods}

\subsection{Cell Culture and Treatments}

Burkitt lymphoma cell lines Ramos and BL41 were cultured in RPMI 1640 medium (Sigma-Aldrich, Saint Louis, MO, USA) supplemented with 10\% FBS and 1\% Penicillin/ streptomycin $(\mathrm{P} / \mathrm{S})$. The cells were maintained at $37^{\circ} \mathrm{C}$ in a humidified incubator supplemented with $5 \% \mathrm{CO}_{2}$. Cells were exposed extracellularly with aldrithiol-2-inactivated HIV-1 virions (HIV-1 AT-2) at $500 \mathrm{ng} / \mathrm{mL}$ or matched microvesicle (MV) control, for $3 \mathrm{~h}$ (virions and MV controls were a kind donation of Professor Jeff Lifson, AIDS and Cancer Virus Program, Frederick National Laboratory USA) [24].

\section{2. miRNA Isolation and PCR Array}

miRNA was isolated using the mirVana ${ }^{\mathrm{TM}}$ miRNA Isolation kit (Thermo Fisher Scientific $^{\mathrm{TM}}$, Waltham, MA, USA) and quantified using the NanoDrop ND-1000 Spectrophotometer (Thermo Fisher Scientific ${ }^{\mathrm{TM}}$, Waltham, MA, USA) and the Qubit ${ }^{\mathrm{TM}}$ RNA Assay kit (Invitrogen, Waltham, MA, USA) as per the manufacturer's protocol. Nucleotide integrity was analysed using gel electrophoresis. miRNA profiling was performed using an Applied Biosystems ${ }^{\mathrm{TM}}$, custom 192a TaqMan ${ }^{\circledR}$ Quantitative real-time PCR low density array (TLDA) card (\#4346802). The 192a-card format was used, and each array card contained mature sequences of 188 miRNAs and three controls (RNU6B, RNU48, RNU44) pre-spotted in duplicate on a 384-well plate array. The RNA isolated from HIV-1 AT-2 and 
microvesicle treated cells ( $1 \mu \mathrm{g}$ per sample) was converted to cDNA using a custom pool of multiplex stem-loop primers and the TaqMan ${ }^{\circledR}$ miRNA Reverse Transcription kit (Thermo Fisher Scientific ${ }^{\mathrm{TM}}$, Waltham, MA, USA), according to the manufacturer's instructions. The cDNA samples were loaded onto the custom TaqMan ${ }^{\circledR}$ Quantitative real-time PCR low density array (TLDA) and target amplification was performed using the TaqMan ${ }^{\circledR}$ Universal PCR Master Mix kit (No AmpErase ${ }^{\circledR}$, UNG 2X) (Thermo Fisher Scientific ${ }^{\mathrm{TM}}$, Waltham, MA, USA) using specific primers and probes on the TaqMan ${ }^{\circledR}$ miRNA microarray. PCR array and data analysis were performed at the Centre for Proteomic and Genomic Research (CPGR, Cape Town, South Africa) using their Applied Biosystems ${ }^{\mathrm{TM}} 7900 \mathrm{HT}$ Real-Time PCR system (Applied Biosystems ${ }^{\mathrm{TM}}$, Carlsbad, CA, USA).

\section{3. miRNA Target and Pathway Analyses}

The bioinformatic predictive tools TargetScan [25], DIANA TarBase [26] and miRDB $[27,28]$ were used to identify gene targets. A list of the top 20 predicted gene targets from each bioinformatic tool was compiled for each miRNA. The Venn diagram creation tool InteractiVenn [29] was used to develop Venn diagrams for the two sets of differentially expressed miRNAs and to identify common gene targets. To identify relevant biological processes and pathways downstream of miRNA gene targets, the database for annotation, visualisation and integrated discovery (DAVID) bioinformatic tool was used [30]. Annotation of enriched biological processes and KEGG pathways downstream of target genes was restricted to those with $p$ values of $\leq 0.05$.

\subsection{RNA Isolation and miRNA Single-Tube TAQMAN ${ }^{\circledR} q P C R$ Assays}

To validate differentially expressed miR-200c-3p, single-tube TaqMan ${ }^{\circledR}$ miRNA assays for hsa-miR-200c-3p and endogenous controls (RNU48, RNU6B) (Applied Biosystems ${ }^{\mathrm{TM}}$, Carlsbad, CA, USA) were performed. Total RNA was isolated from treated cells and reverse transcription performed (10 ng per sample) using specific stem-loop primers and the TaqMan ${ }^{\circledR}$ miRNA Reverse Transcription kit (Applied Biosystems ${ }^{\mathrm{TM}}$, Carlsbad, CA, USA). This was followed by qPCR using specific primer pairs (hsa-miR-200c-3p and controls) and the TaqMan ${ }^{\circledR}$ Universal PCR Master Mix kit (No AmpErase ${ }^{\circledR}$, UNG 2X) (Applied Biosystems ${ }^{\mathrm{TM}}$, Carlsbad, CA, USA). The qPCR and analysis were performed using the Roto-Gene Q 2356 (Qiagen, Hilden, Germany). The delta CT method was used to analyse the expression of the genes of interest relative to the internal control in each of the samples. Comparison was made between the HIV-treated and control MV-treated cells using the fold-change $\left(2^{-\Delta \Delta C T}\right)$, where the control group was set to 1 .

\section{5. cDNA Synthesis and qPCR for ZEB1 and ZEB2}

Reverse transcription was performed using the iScript ${ }^{\mathrm{TM}} \mathrm{cDNA}$ Synthesis Kit (Bio Rad, Hercules, CA, USA) according to the manufacturer's recommendations and the cDNA was used as a template for quantitative PCR using the KAPA SYBR ${ }^{\circledR}$ FAST qPCR Kit (Kapa Biosystems, Western Cape, South Africa). The primer sets used for amplification were GAPDH, forward 5'-GAAGGCTGGGGCTCATTT-3 ${ }^{\prime}$, reverse- $5^{\prime}$-CAGGAGGCATTGCTGA TGAT-3'; ZEB1, forward 5'-GCCTGAAATCCTCTCTGAATG-3' ${ }^{\prime}$, reverse $5^{\prime}$-CACCTCTTGTC AAAC-3' ; ZEB2, forward 5'-GAAGAGACTGGAGATCACTC-3' and reverse $5^{\prime}$-GCCATCTT CCATATTGTC-3'. The expression of GAPDH was used as the internal control. Comparison was made between the HIV-treated and control MV-treated cells using the foldchange $\left(2^{-\Delta \Delta C T}\right)$, where the control group was set to 1 .

\subsection{Total Protein Isolation and Western Blot Analyses}

Total protein was isolated from treated cells using RIPA buffer (150 mM NaCl, Tris $\mathrm{pH} 7.5,1 \%$ Triton $\mathrm{X}-100,0.1 \%$ SDS, $10 \mathrm{Mm}, 1 \%$ deoxycholate powder and $1 \times$ protease inhibitor) and incubated overnight at $-80^{\circ} \mathrm{C}$ for optimum cell lysis. The lysed cells were centrifuged at $4^{\circ} \mathrm{C}$ for $20 \mathrm{~min}$ and the supernatant (containing protein) was quantified using the Pierce ${ }^{\mathrm{TM}}$ BCA assay kit (Thermo Fisher Scientific ${ }^{\mathrm{TM}}$, Waltham, MA, USA). Twenty 
micrograms of protein were separated using $8 \%$ SDS-PAGE gels. The separated proteins were transferred to nitrocellulose membranes (Bio-Rad, Hercules, CA, USA) using the Mini-PROTEAN 3 casting apparatus (Bio-Rad, Hercules, CA, USA). The membrane was blocked in $5 \%(w / v)$ fat-free milk in $1 \times$ PBS-Tween and incubated overnight at $4{ }^{\circ} \mathrm{C}$ with the following antibodies: ZEB1 (sc-25388, Santa Cruz Biotechnology, Dallas, TX, USA; 1:1000), ZEB2 (SIP1, sc-48789, Santa Cruz Biotechnology, Dallas, TX, USA; 1:1000) and p38 (Bio-Rad, Hercules, CA, USA; 1:5000). The secondary antibodies used were Goat Anti Rabbit (H + L) HRP conjugate (170-6515, Bio-Rad, Hercules, CA, USA; 1:5000) and Goat Anti Mouse (H + L) HRP conjugate (170-6516, Bio-Rad, Hercules, CA, USA; 1:5000).

\subsection{Transwell Migration Assay}

Cell migration was measured using a migration assay 2-chamber system (Transwell ${ }^{\circledR}$ migration assays, Corning, NY, USA). Briefly, medium supplemented with $10 \%$ FBS was added to the bottom chamber and the Transwell ${ }^{\circledR}$ chambers $(8 \mu \mathrm{m}$ pore size) were placed on top, into which cells were seeded in low-serum medium (0.5\% FBS). Migration was allowed to proceed for $24 \mathrm{~h}$. The cells in the upper side of the chamber were carefully removed. The migrated cells on the bottom of the membrane were fixed using $100 \%$ methanol and stained using $0.2 \%$ crystal violet, air-dried and thereafter solubilized in $50 \%$ acetic acid. The absorbance was read at $595 \mathrm{~nm}$.

\subsection{Statistical Analyses}

For the miRNA PCR array data, the SDS output file (output format from the Applied Biosystem's qRT-PCR instrument ABI7900HT) was converted to plain text using Applied Biosystem's RQ Manager (version 1.2). Bioconductor's HTqPCR package (Dvinge \& Bertone, 2009) was used in R (R Development Core Team, 2013) to analyse the qRT-PCR data [31]. Each amplification plot was viewed using RQ Manager (Applied Biosystems ${ }^{\mathrm{TM}}$, Carlsbad, CA, USA) whereby the baseline and threshold values were set manually; failed replicates were excluded and only probes with two or more replicates were retained. The data were then exported into the DataAssist ${ }^{\mathrm{TM}}$ software (version 3.01) (Applied Biosystems ${ }^{\mathrm{TM}}$, Carlsbad, CA, USA) to generate the $\mathrm{Ct}$ values for each replicate. $\mathrm{Ct}$ values between 30 and 37 were retained and the median value was calculated. The data were normalised using the geometric mean method [32]. The delta Ct method $\left(2^{-\Delta \Delta \mathrm{Ct}}\right)$ was used to determine the fold change in expression of miRNAs and those that exhibited a fold change of two or more (FDR adjusted $p$-value $\leq 0.06$ ) were selected for further analysis. Student's $t$-test (two-tailed) was used to test for significance between the HIV and MV-treated samples. For miRNA validation and all other qPCR data, the RotorGene $Q$ software was used to analyse and determine the Ct values. Student's $t$-test (two-tailed) was used for comparison of the normalised data between the HIV-treated and MV-treated groups. All normally distributed data are presented as means \pm SEM and significance determined using the two-sample $t$-test (Microsoft Excel for Office 365 or GraphPad Prism version 8). The latter was applied to the single-tube miRNA qPCR assays, qPCR assays for ZEB1 and ZEB2, and the migration assays.

\section{Results}

\subsection{Exposure to HIV-1 Leads to Significant Changes in the miRNA Profile of Burkitt Lymphoma Cells}

We designed a custom microarray based on the most common miRNAs reported to be deregulated in diffuse large B-cell lymphoma and Burkitt lymphoma (Supplementary Tables S1-S3). Among people living with HIV, these cancers represent the two most prevalent non-Hodgkin lymphomas (NHLs) within this population group. However, the deregulation of these miRNAs within the context of HIV remains unknown. We thus performed a differential screening, using this custom-designed array to assess changes in the expression landscape of these miRNAs within an HIV-positive context. Cells derived from the Burkitt lymphoma cell line Ramos were exposed to HIV-1 AT-2, and the miR- 
NAome was assessed and compared to control cells (exposed to matched microvesicles). HIV-1 virions treated with Alrithiol-2 (AT-2), a mild oxidising agent, lose the ability to infect cells as a result of loss of sulphide bonds between the cysteine residues of the nucleocapsid proteins [24], but the structural integrity of the glycoproteins on the surface of the virions remains unaffected, ensuring that they retain the ability to interact with cell surface receptors. Following exposure for $3 \mathrm{~h}$, thirty-two (32) miRNAs were found to be differentially expressed, by 2-fold or more (with a threshold of significance of $p \leq 0.06$ ), in HIV exposed cells when compared to control cells (Figure 1a). This therefore indicates that the pathobiology of HIV-associated NHLs provides a cellular microenvironment that alters miRNA pathways in a way that is distinct from one where HIV is not present.

(a)

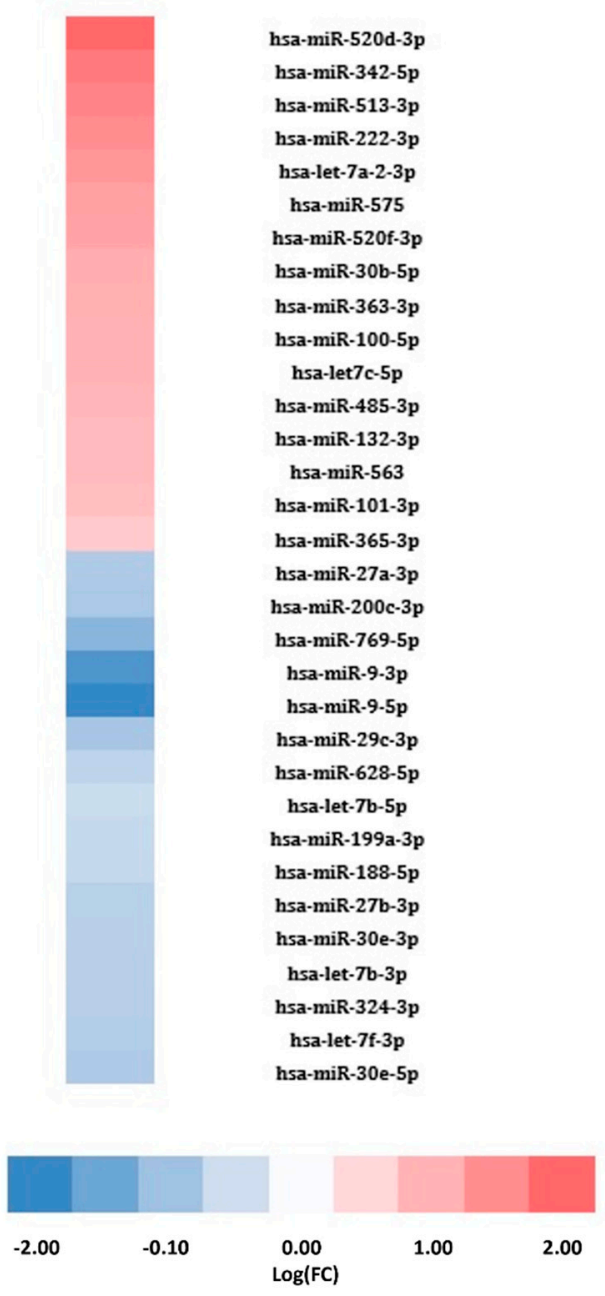

\section{(b)}

Target genes of upregulated miRNAs

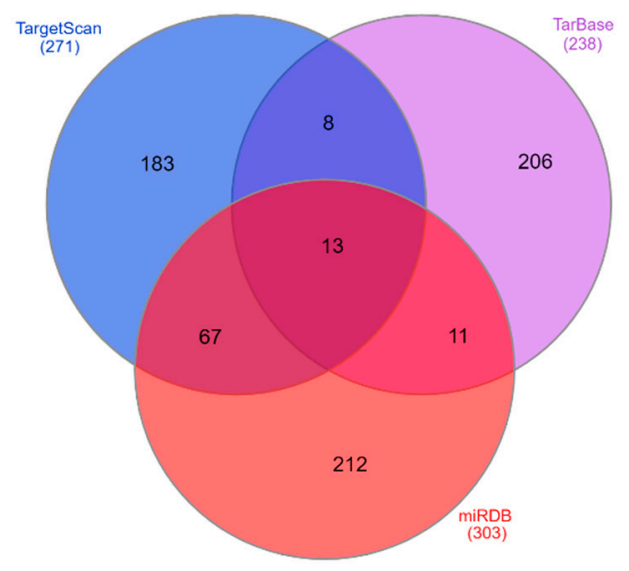

Target genes of downregulated miRNAs

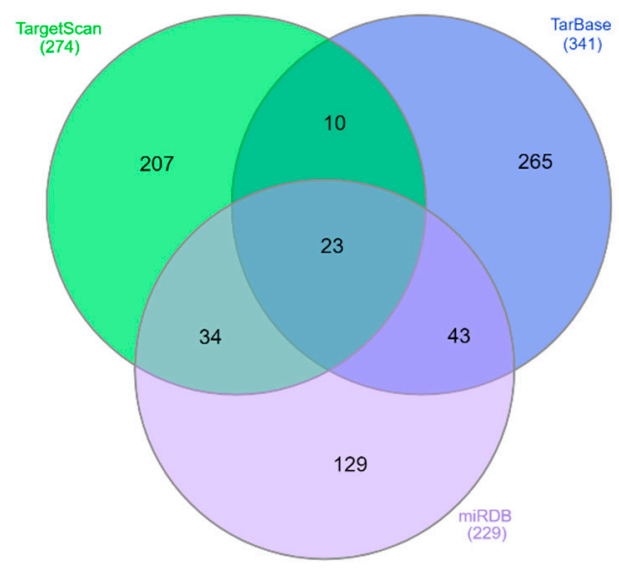

Figure 1. miRNAs differentially expressed by 2-fold or more (with a threshold of significance of $p \leq 0.06$ ) in Ramos cells exposed to HIV-1 AT-2 compared to matched microvesicle cells (control), and alteration of predicted genes. (a) Heat map showing differentially expressed miRNAs, data represented as $\log (\mathrm{FC})$. (b) Venn diagram showing predicted miRNA gene targets identified by three independent bioinformatic tools (TargetScan, Tarbase and miRDB).

We next sought to better define the role of these miRNAs in order to understand how they contribute to the HIV-associated NHL cancer phenotype. Using three independent predictive bioinformatics tools (TargetScan [25], DIANA TarBase [26] and miRDB [27,28]), the top 20 genes potentially targeted by each of the 32 miRNAs were identified and analysed, revealing 13 and 23 genes commonly targeted among all three databases, for 
upregulated and downregulated miRNAs, respectively (Figure $1 \mathrm{~b}$ and Table 1 ). The analysis of biological processes and pathways associated with these 36 genes reveals associations with a variety of cellular processes and pathways, but notably with B-cell differentiation, cell cycling, proliferation, DNA damage and drug responses, and several typical KEGG cancer pathways (Figure 2). For instance, miR-222-3p, which we found to be upregulated by $\sim 7$-fold in our array, has previously been shown to be downregulated in $B L$ relative to DLBCL [33], and specifically targets the cyclin-dependent kinase inhibitor p27 Kip1 [34]. Within an HIV-positive environment, an upregulation of this miRNA would therefore translate to enhanced cellular proliferation, a pertinent feature of these aggressive HIV-associated cancers. Other miRNAs with known roles in cancer-promoting processes identified in the array include miR-575, miR-363-3p and several others. Of particular interest was hsa-miRNA-200c-3p, which, in addition to having a high association with numerous cancer types, has previously been reported to be downregulated in DLBCL [35].

Table 1. List of commonly predicted gene targets of upregulated and downregulated miRNAs in BL cells exposed to HIV-1.

\begin{tabular}{cc}
\hline $\begin{array}{c}\text { Predicted Gene Targets of Upregulated } \\
\text { miRNAs (13) }\end{array}$ & $\begin{array}{c}\text { Predicted Gene Targets of Downregulated } \\
\text { miRNAs (23) }\end{array}$ \\
\hline & NOVA1, FBXW7, ZEB1, GABRA1, POU2F1, \\
CDKN1B, KIT, MIDN, ANKRA2, FNIP1, BTG2, & $M T H F D 2$, LIN28B, TET1, COL3A1, HMGA2, \\
HS3ST2, CTDSPL, SMARCA5, MTOR, TRIM71, & KLHL3, SERPINE2, PAWR, GNA12, PAK4, \\
$M Y C N$, ACVR1 & $B C A R 3$, CD2AP, FOXN2, ZFP91, SLC22A3, \\
& $P T E N$, C6orf106, SRSF7 \\
\hline
\end{tabular}

(a)

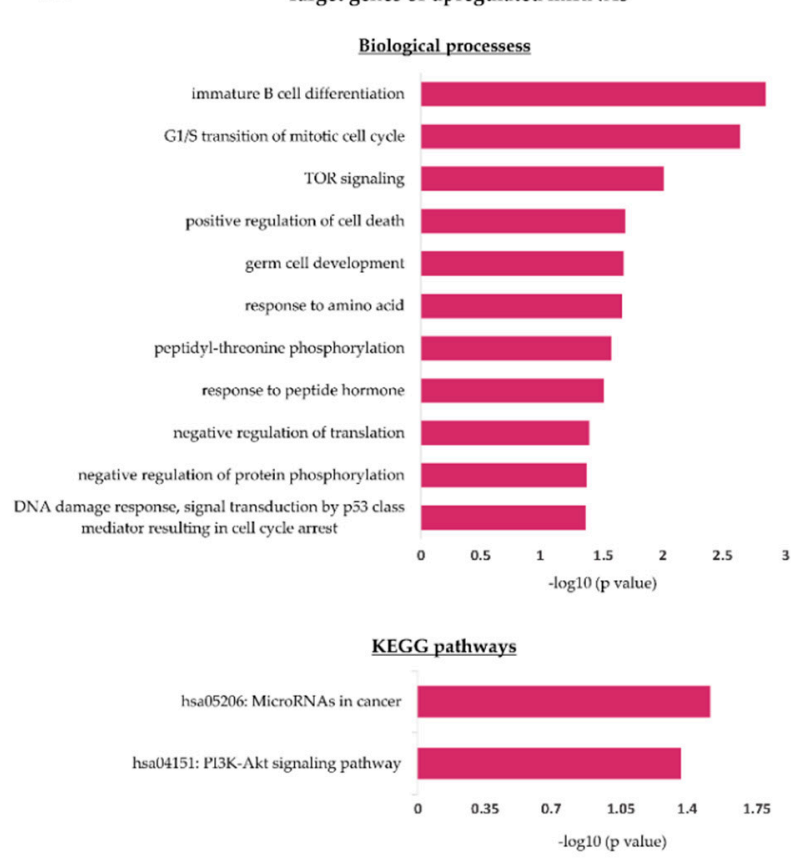

(b)

Target genes of downregulated miRNAs

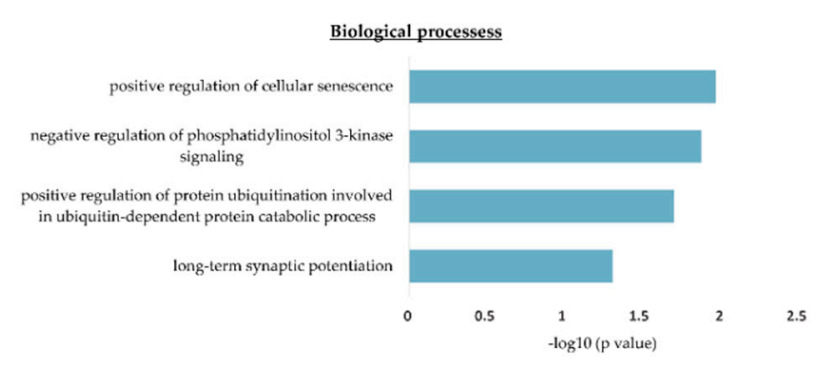

KEGG pathways

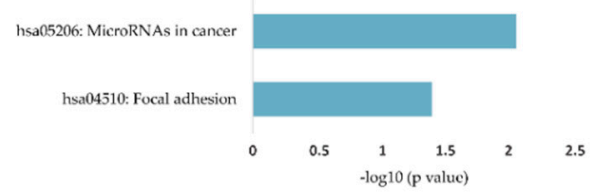

Figure 2. Biological process and KEGG pathway analysis of predicted target genes of differentially expressed miRNAs in Ramos cells exposed to HIV-1 AT-2. Biological processes (upper bar graph) and KEGG pathways (lower bar graph) significantly associated with predicted gene targets of upregulated (a) and downregulated (b) miRNAs. Data are represented as $-\log 10$ ( $p$ value); only significantly enriched associations were annotated $(p<0.05)$. 
3.2. Hsa-miR-200c-3p Is Significantly Downregulated in HIV-1 Treated Burkitt Lymphoma Cells, and This Is Associated with Enhanced Migration

We found the expression of hsa-miR-200c-3p to be downregulated by greater than 6.67-fold in the array. The validity of this observation was strengthened when single-tube miRNA assays showed that miR-200c-3p was indeed significantly downregulated in the Ramos cells (2-fold), as well as in a second BL cell line, BL41 (2-fold), when these cells were exposed to HIV-1, relative to controls (Figure 3a,b). The miRNA-200 family, which is highly conserved among vertebrates, has been shown to play a key role in cancer, from cancer initiation to metastasis [22]. Not only has it been shown to be downregulated in B-cell lymphomas, but also in cancers of the breast, lung, oesophagus, stomach, colon and many others. Importantly, the use of this miRNA as a prognostic marker looks promising, showing a favourable positive predictive value when evaluated in the plasma levels of cancer patients. Although reported to be involved in a variety of cancer types and cellular processes (Table 2), the miRNA-200 family is particularly associated with inhibition of the epithelial-to-mesenchymal transition, an early step in metastasis, by maintaining the epithelial phenotype through directly targeting the transcriptional repressors [36]. In lymphoma, the role of miRNA-200c remains unclear, with reports of both upregulation and downregulation of this microRNA [37,38]. In order to ascertain whether this downregulation was physiologically relevant, the migratory ability of the BL cells when exposed to HIV-1 was investigated. A validated in vitro assay was used, consisting of a two-chamber system separated by a porous membrane, and differential chemoattractant (FBS) in the two chambers. The extent of cellular migration was determined $24 \mathrm{~h}$ post-treatment. Indeed, both Ramos and BL41 cells displayed significantly enhanced migratory abilities in the presence of HIV-1, compared to control cells. The migration rates increased by $32 \%$ and $37 \%$ for Ramos and BL41 cells, respectively (Figure 3c,d).

Table 2. Selected list of experimentally validated gene targets of hsa-miR-200c-3p and the supporting literature.

\begin{tabular}{|c|c|c|c|}
\hline Gene Target & Validation Tool & Cancer Type: Process & Reference \\
\hline $\begin{array}{l}\text { Zinc Finger E-box Binding Protein } 1 \text { and } 2 \\
\text { (ZEB1, ZEB2) }\end{array}$ & $\begin{array}{l}\text { Dual-luciferase reporter assay, Western } \\
\text { blotting, qPCR }\end{array}$ & $\begin{array}{l}\text { Gastric, Head and neck squamous cell } \\
\text { carcinoma (HNSCC): } \\
\text { Epithelial-to-mesenchymal transition } \\
\text { (EMT), migration and invasion. }\end{array}$ & {$[23,39]$} \\
\hline $\begin{array}{l}\text { X-linked inhibitor of apoptosis protein } \\
\text { (XIAP), B-cell lymphoma } 2 \text { (BCL2) }\end{array}$ & $\begin{array}{l}\text { Dual-luciferase reporter assay, Western } \\
\text { blotting }\end{array}$ & Gastric, Lung: apoptosis & [40] \\
\hline Tubulin $\beta 3$ Class III (TUBB3) & $\begin{array}{c}\text { Dual-luciferase reporter assay, Western } \\
\text { blotting, qPCR }\end{array}$ & $\begin{array}{l}\text { Breast, Ovarian, endometrial: } \\
\text { proliferation, drug resistance }\end{array}$ & {$[41,42]$} \\
\hline KRAS proto-oncogene (KRAS) & $\begin{array}{c}\text { Dual-luciferase reporter assay, Western } \\
\text { blotting }\end{array}$ & Breast, NSCLC: Proliferation & [43] \\
\hline $\begin{array}{l}\text { B-cell-specific Moloney murine leukaemia } \\
\text { virus insertion site } 1 \text { (BMI1), E2F } \\
\text { transcription factor 3 (E2F3) }\end{array}$ & Reporter assay, Western blotting, qPCR & $\begin{array}{l}\text { Renal, Bladder: Proliferation, migration, } \\
\text { and invasion }\end{array}$ & {$[44,45]$} \\
\hline Fibronectin 1 (FN1), Moesin (MSN) & Reporter assay, Western blotting, qPCR & $\begin{array}{l}\text { Breast, endometrial: Invasion, anoikis } \\
\text { resistance }\end{array}$ & {$[46,47]$} \\
\hline
\end{tabular}

Inhibitor of Nuclear Factor Kappa $\beta$

Kinase Subunit $\beta$ (IKBK $\beta)$, Fms Related

Receptor Tyrosine Kinase 1 (FLT1),

Reporter assay, Western blotting, qPCR Endometrial: Proliferation, inflammation

Kruppel Like Factor 9 (KLF9) 
(a)

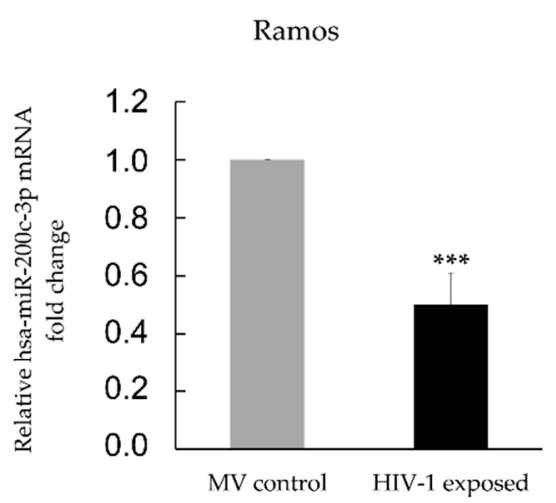

(c)

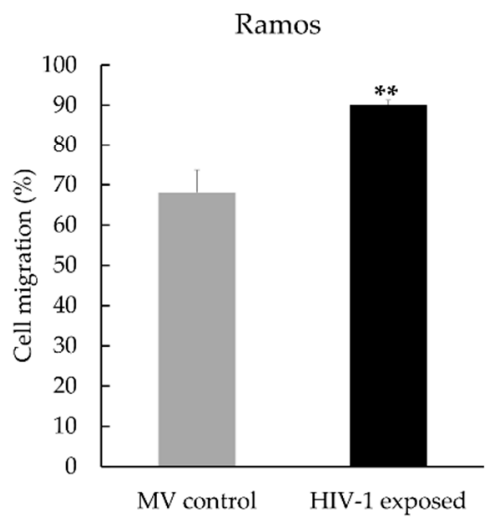

(b)

BL41

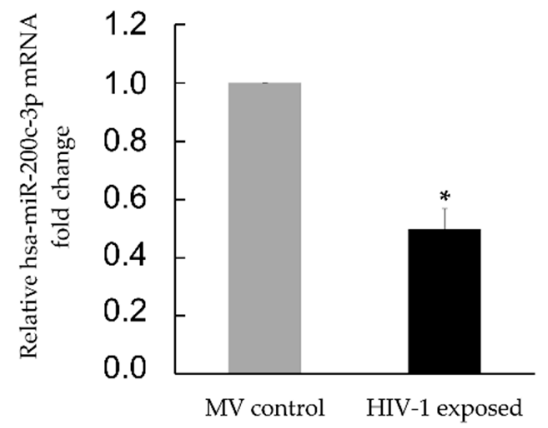

(d)

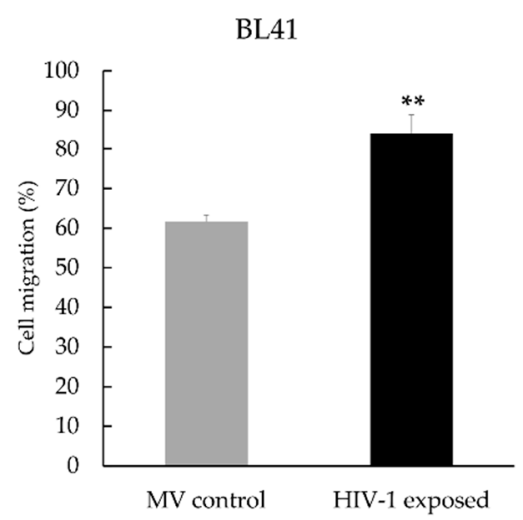

Figure 3. The downregulation of hsa-miR-200c-3p in HIV-1 AT-2 treated cells correlates with enhanced cell migration. (a) Fold change in miR-200c-3p expression in Ramos and (b) in BL41 cells exposed to HIV-1 AT-2 compared to control microvesicle-exposed cells. The cells were treated with either HIV-1 AT-2 or microvesicles and thereafter RNA was isolated. TaqMan ${ }^{\circledR}$ single-tube miRNA assays were used for RT-qPCR and the delta Ct $\left(2^{-\Delta \Delta C t}\right)$ method was used for quantification. (c) Fold change in migration in Ramos cells and (d) in BL41 cells exposed to HIV-1 AT-2 compared to control microvesicleexposed cells. Cells were treated as described above and Transwell ${ }^{\circledR}$ migration assays were used to measure migratory ability. The treated cells were plated in low-serum medium $(0.5 \%$ FBS $)$ on the top chamber, and allowed to migrate to the bottom nutrient-rich (10\% FBS) medium. Migrated cells were stained and absorbance readings (correlating to the number of cells) were taken. The data were normalised to the total number of plated cells. Student's $t$-test was performed to determine statistical significance. $\left({ }^{*} p<0.05,{ }^{* *} p<0.01,{ }^{* * *} p<0.001\right)$ and error bars represent standard deviation.

\subsection{MiR-200c-3p Downregulation and Enhanced Migration Correlates with Over-Expression of ZEB1 and ZEB2 Proteins in BL Cells}

The Zinc Finger E-box Binding (ZEB) family of transcription factors has been experimentally confirmed in numerous studies to be targeted by miR-200c $[39,49]$. These proteins have been described as master regulators of epithelial-to-mesenchymal transition (EMT), through their ability to regulate genes involved in cell plasticity, intercellular adhesions and degradation of the extracellular matrix [50]. ZEB1 was one of the top 20 targets, from three databases, found to be potentially upregulated in our array (Table 1). At the mRNA level, we found ZEB1 to be significantly downregulated in both Ramos (1.75-fold) and BL41 cells (1.30-fold), when exposed to HIV-1 (Figure 4a,b). Conversely, at the protein level, there was an increase in ZEB1 protein expression in both the Ramos (2.75-fold) and BL41 (1.33-fold) cells (Figure 4c,d). A very similar pattern was observed when the expression of ZEB2 was investigated. The expression of the ZEB2 mRNA was significantly reduced in both cell lines upon exposure to HIV-1 (Figure 5a,b), with a decrease of 2.04-fold in Ramos cells, and of 1.30-fold in BL41 cells. As for ZEB1, the expression of the ZEB2 protein was 
enhanced in both the Ramos cells (1.99-fold), as well as the BL41 cells (2.78-fold) upon exposure to HIV-1 (Figure 5c,d).

(a)

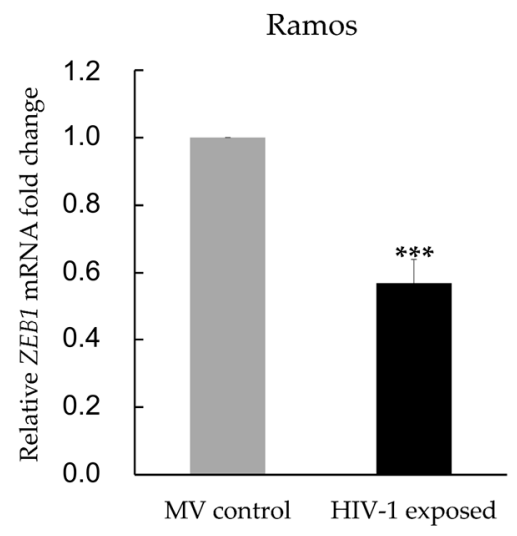

(c)

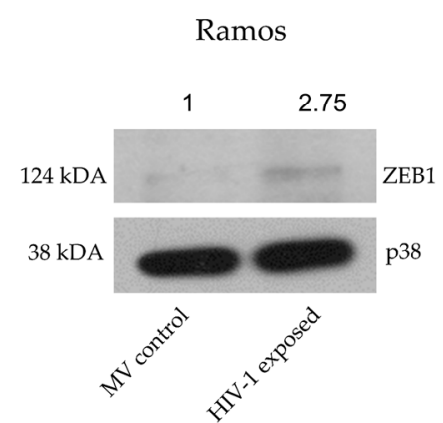

(b)

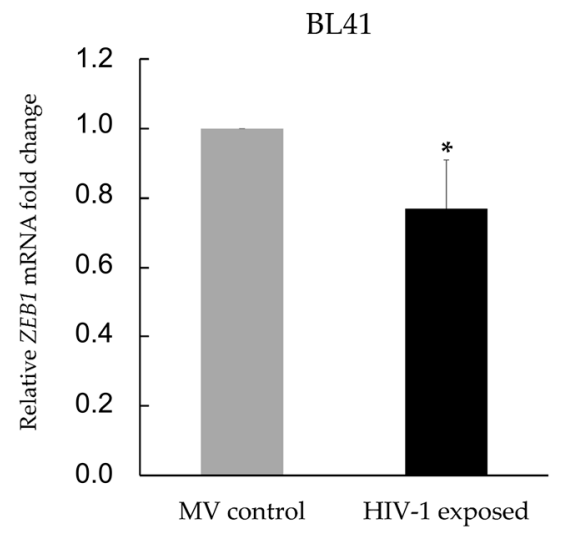

(d)

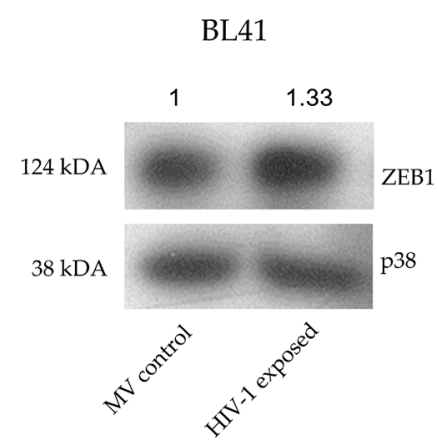

Figure 4. HIV-1 AT-2 deregulates expression of ZEB1 in BL cells. The cells were treated with either HIV-1 AT-2 or microvesicles and thereafter RNA $(\mathbf{a}, \mathbf{b})$ or protein $(\mathbf{c}, \mathbf{d})$ was isolated. mRNA expression of ZEB1 in Ramos (a) and BL41 (b) cells treated with HIV-1 AT-2 as determined by RT-qPCR. Protein expression of ZEB1 in Ramos (c) and BL41 (d) cells, as determined by Western blotting, using p38 as loading control. For $(\mathbf{a}, \mathbf{b})$, the delta $\mathrm{Ct}\left(2^{-\Delta \Delta \mathrm{Ct}}\right)$ method was used and Student's $t$-test was performed to determine statistical significance. $\left({ }^{*} p<0.05,{ }^{* * *} p<0.001\right)$ and the error bars represent standard deviation. 
(a)

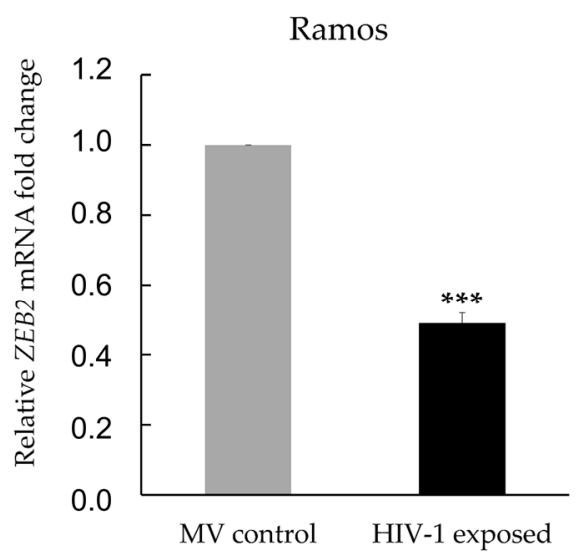

(c)

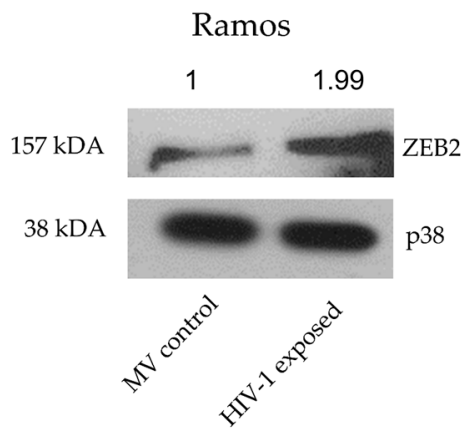

(b)

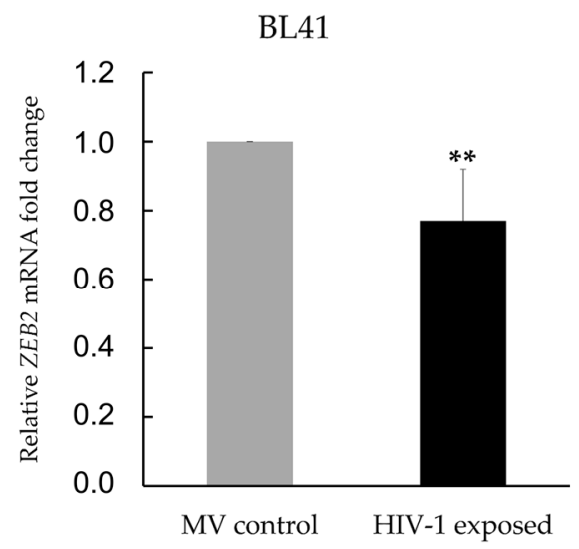

(d)

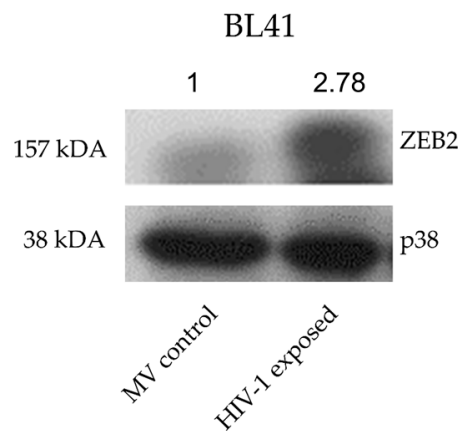

Figure 5. HIV-1 AT-2 deregulates expression of ZEB2. The cells were treated with either HIV-1 AT-2 or microvesicles and thereafter RNA was isolated after treatment. mRNA expression of ZEB2 in (a) Ramos and (b) BL41 cells treated with HIV-1 AT-2 was determined using RT-qPCR. Western blot and quantification analysis of ZEB2 protein expression in (c) Ramos and (d) BL41 cells treated with HIV-1 AT-2 compared to control cells. For (a,b), the delta Ct $\left(2^{-\Delta \Delta C t}\right)$ method was used for quantification and Student's $t$-test was performed to determine statistical significance. $\left({ }^{* *} p<0.01,{ }^{* *} p<0.001\right)$ and the error bars represent standard deviation.

\section{Discussion}

People living with HIV are at increased risk of developing cancer, with non-Hodgkin lymphoma being one of the most prevalent cancers within this group [8]. While traditionally this enhanced risk was associated with HIV-1-induced immune suppression and exhaustion, as well as chronic B-cell activation, the advent of antiretroviral therapy (ART), even at early stages of infection, did not abolish this risk [51]. There is now enough experimental evidence to support an oncogenic role for HIV-1 and its antigens in carcinogenesis [52]. HIV-1 does not infect B lymphocytes; however, the virus is capable of binding these cells through cell surface receptors [20], and so can components of the virus, as has been demonstrated by binding of the p17 matrix protein to the CXCR receptors [53].

Whether through cell surface signalling, or via internalization, HIV-1 has the ability to alter cellular processes at multiple levels. In the current study, using a custom array design based on frequently reported altered miRNAs in the two most prevalent HIV-associated NHLs, we identified 32 miRNAs that were differentially expressed, out of 188 selected, in BL cells exposed to HIV-1, relative to controls. To the best of our knowledge, this is the first study to report on differentially expressed miRNAs in Burkitt lymphoma cells exposed to HIV-1. The relationship between HIV-1 and cellular miRNAs is well described. The virus and components of the virus have previously been reported to alter expression of cellular miRNAs in other cellular contexts. In a recent study, the T-cell lymphoblastic 
lymphoma SupT1 cell line showed alteration of several cellular miRNAs upon infection with HIV [54]. In fact, the alteration of host miRNA networks in CD4+ cells seems to be crucial for successful viral invasion and latency. Within the context of HIV non-host cells, there are a few reports of alterations in miRNAs due to the presence of the virus or its antigens. For instance, in Kaposi's sarcoma (KS), the HIV-1 Tat protein has been shown to synergize with the KSHV oncogene Orf-K1 to induce miR-891a-5p, modulating NF-kB [55]. There has not, as yet, been any comprehensive study on large-/medium-scale differential miRNA expression in NHLs comparing HIV-positive with HIV-negative. An earlier study conducted on a cohort in Kenya measured the expression of only a selected number of miRNAs, linked to the regulation of DNA methyltransferase (DNMT), from HIV-related NHLS (formalin-fixed paraffin embedded tumours) and compared that to expression in HIV-negative controls [56].

MiRNA in silico prediction analyses allowed for the identification of 36 putative targets (13 potentially downregulated, and 23 potentially upregulated). The miRNA interactome is complex, with single miRNAs shown to be able to target dozens of genes, and this therefore hinders straightforward interpretation of differences in miRNA expression. Importantly, a majority of the predicted targets identified from our miRNA array, and their associated biological processes, were found to be associated with cancer hallmarks with a high degree of confidence. Nevertheless, experimental validation is essential to assess true physiological impact, and thus, using single-tube miRNA assays, hsa-miR-200c-3p was confirmed as significantly downregulated in BL cells exposed to HIV-1. This downregulation was strongly associated with enhanced cellular migration, a physiological function linked to this miRNA (36). The role and significance of miR-200c-3p in BL development has not been clearly defined. In many cancers such as breast, ovarian and endometrial cancers, miR-200c-3p has been identified to have a tumour suppressor role [41,48,57]. The miR-200 family cluster of miRNAs have been termed "the guardians of the epithelial phenotype", as they have been found to be enriched in epithelial tissues and epigenetically silenced in mesenchymal tissues $[42,58]$. Along with other miRNA, members of the miR-200 family have been shown to be a marker of the epithelial phenotype since miR-200c-3p targets numerous mesenchymal genes and inhibits tumour cell migration and invasion [59].

ZEB1 and ZEB2 are two mesenchymal genes that are direct targets of miR-200c$3 p[36,39,48,60]$ and we thus sought to find a correlation between them within our model system. We found the mRNA expression of both ZEB1 and ZEB2 to be significantly downregulated in response to HIV-1 exposure in both cell lines (Figure 4a,b and Figure 5a,b). Although an inverse correlation is expected, assessment of changes in the transcription level of miRNA targets can be misleading. This is because miRNA may bind to mRNA and prevent translation, with no change in mRNA levels, and this has been demonstrated in several studies [61]. We speculate that the downregulation of ZEB transcription observed upon HIV-1 exposure in our study results from a different mechanism and could represent an attempt by the cellular machinery to mitigate the deleterious effects of this highly oncogenic factor. ZEB is known to be regulated at multiple levels through a complex web of intracellular signalling pathways and it would be difficult to pinpoint the exact mechanism without a global view of the regulatory landscape within B cells in an HIVpositive background, and this supports the need for more research in this field [62]. It is, however, important to note that ZEB transcription is not abrogated when exposed to HIV-1, and sufficient mRNA is still being produced to lead to enhanced protein expression.

Interestingly, there is a double-negative feedback loop that exists between the ZEB transcription factors and the miR-200 family, where these proteins can directly bind to and inhibit the expression genes encoding for the miR-200 family $[63,64]$. This feedback loop is advantageous to cells, as it allows for easy and reversible switching between epithelial and mesenchymal characteristics, depending on extracellular signals [65]. Contrary to the mRNA, the expression of ZEB1 and ZEB2 protein was upregulated in Burkitt lymphoma cells upon exposure to HIV-1, supporting the notion that the enhanced migration of BL 
cells via downregulation of hsa-miR-200c-3p leads to an alleviation of active repression of the ZEB proteins.

Although still poorly understood, it is important to note that the mechanisms driving malignant cell migration are highly complex and involve several coordinated events including development of cytoplasmic protrusions, changes in cellular adhesion and traction, expression of proteolytic enzymes and more [66]. The ZEB proteins are part of a group of transcription factors (including Snail, Slug, KLF8 and others) that regulate this process, and while they have been shown to be specifically involved with cell plasticity, for instance through their ability to repress the adhesion molecule E-cadherin, they contribute to several other cellular events that promote cancer, such as enhancing cell cycling and acquisition of drug resistance [64]. Similarly, although the role of hsa-miR-200c-3p in cancer cell migration is well described, several other miRNAs have been identified to play pertinent roles in this specific function $[67,68]$. It is therefore clear that an array of factors and mechanisms is needed to drive cancer cell migration, and that in this particular study, while the hsa-miR-200c-3p/ZEB axis has been identified as a role player, it is as yet an association that needs to be confirmed via further loss- and gain-of-function analyses.

This study therefore contributes to accumulating evidence that HIV-1 can directly promote oncogenic pathways in B-cell lymphoma, and clinical studies should be conducted to evaluate the use of hsa-miR-220c-3p as a potential novel biomarker that can be used for prognosis in patients with Burkitt lymphoma, who are HIV positive.

Supplementary Materials: The following are available online at https://www.mdpi.com/article/10 .3390/genes12091302/s1, Table S1: Summary of miRNAs reported to be deregulated in Diffuse Large B-cell lymphoma, Table S2: Summary of miRNAs reported to be deregulated in Burkitt lymphoma, Table S3: MiRNAs ( $\mathrm{n}=188$; 192a format) for microarray profiling, spotted in duplicate, including four controls.

Author Contributions: Conceptualization, T.G.-H., B.R.R. and S.M.; methodology, T.G.-H., B.R.R. and L.A.d.S.R.; validation, B.R.R.; formal analysis, B.R.R. and L.A.d.S.R.; investigation, B.R.R. and T.G.-H.; resources, S.M.; data curation, L.A.d.S.R. and B.R.R.; writing-original draft preparation, B.R.R. and T.G.-H.; writing-review and editing, S.M., B.R.R. and L.A.d.S.R.; visualisation, B.R.R., L.A.d.S.R. and S.M.; supervision, S.M.; project administration, B.R.R. and S.M.; funding acquisition, S.M. All authors have read and agreed to the published version of the manuscript.

Funding: This research was funded by the South African National Research Foundation (NRF), The South African Medical Research Council (SAMRC), the National Health Laboratory Service (NHLS) and The University of Cape Town.

Institutional Review Board Statement: Not applicable.

Informed Consent Statement: Not applicable.

Data Availability Statement: Not applicable.

Acknowledgments: We would like to thank the following for their contributions: Dave Sandeep (Duke University, USA) for the kind donation of the BL41 cell line. Jeff Lifson (NIH, USA) and Wendy Burgers, Division of Medical Virology, Department of pathology (UCT) for donating the HIV-1 virions and microvesicles. Nicki Adams and Wendy Kröger at the Centre for Proteomic and Genomic Research (CPGR).

Conflicts of Interest: The authors declare no conflict of interest.

\section{References}

1. Ambros, V.; Bartel, B.; Bartel, D.P.; Burge, C.B.; Carrington, J.C.; Chen, X.; Dreyfuss, G.; Eddy, S.R.; Griffiths-Jones, S.; Marshall, M.; et al. A uniform system for microRNA annotation. RNA 2003, 9, 277-279. [CrossRef] [PubMed]

2. De Tullio, G.; De Fazio, V.; Sgherza, N.; Minoia, C.; Serratì, S.; Merchionne, F.; Loseto, G.; Iacobazzi, A.; Rana, A.; Petrillo, P.; et al. Challenges and Opportunities of MicroRNAs in Lymphomas. Molecules 2014, 19, 14723-14781. [CrossRef]

3. MacFarlane, L.; Murphy, P.R. MicroRNA: Biogenesis, Function and Role in Cancer. Curr. Genom. 2010, 11, 537-561. [CrossRef] [PubMed] 
4. Iorio, M.V.; Ferracin, M.; Liu, C.G.; Veronese, A.; Spizzo, R.; Sabbioni, S.; Magri, E.; Pedriali, M.; Fabbri, M.; Campiglio, M.; et al. MicroRNA gene expression deregulation in human breast cancer. Cancer Res. 2005, 65, 7065-7070. [CrossRef]

5. Ranganathan, K.; Sivasankar, V. MicroRNAs-Biology and clinical applications. J. Oral Maxillofac. Pathol. JOMFP 2014, 18, 229-234. [CrossRef] [PubMed]

6. Cheng, A.M.; Byrom, M.W.; Shelton, J.; Ford, L.P. Antisense inhibition of human miRNAs and indications for an involvement of miRNA in cell growth and apoptosis. Nucleic Acids Res. 2005, 33, 1290-1297. [CrossRef]

7. Swerdlow, S.H.; Campo, E.; Pileri, S.A.; Harris, N.L.; Stein, H.; Siebert, R.; Advani, R.; Ghielmini, M.; Salles, G.A.; Zelenetz, A.D.; et al. The 2016 revision of the World Health Organization classification of lymphoid neoplasms. Blood 2016, 127, 2375-2390. [CrossRef]

8. Re, A.; Cattaneo, C.; Rossi, G. Hiv and Lymphoma: From Epidemiology to Clinical Management. Mediterr. J. Hematol. Infect. Dis. 2019, 11, e2019004. [CrossRef]

9. Sissolak, G.; Seftel, M.; Uldrick, T.S.; Esterhuizen, T.M.; Mohamed, N.; Kotze, D. Burkitt's Lymphoma and B-Cell Lymphoma Unclassifiable with Features Intermediate Between Diffuse Large B-Cell Lymphoma and Burkitt's Lymphoma in Patients With HIV: Outcomes in a South African Public Hospital. J. Glob. Oncol. 2017, 3, 218-226. [CrossRef]

10. Pannone, G.; Zamparese, R.; Pace, M.; Pedicillo, M.; Cagiano, S.; Somma, P.; Errico, M.; Donofrio, V.; Franco, R.; De Chiara, A.; et al. The role of EBV in the pathogenesis of Burkitt's Lymphoma: An Italian hospital based survey. Infect. Agents Cancer 2014, 9 , 34. [CrossRef] [PubMed]

11. Schmitz, R.; Ceribelli, M.; Pittaluga, S.; Wright, G.; Staudt, L.M. Oncogenic Mechanisms in Burkitt Lymphoma. Cold Spring Harb. Perspect. Med. 2014, 4, a014282. [CrossRef]

12. Lim, S.T.; Karim, R.; Nathwani, B.N.; Tulpule, A.; Espina, B.; Levine, A.M. AIDS-Related Burkitt's Lymphoma Versus Diffuse Large-Cell Lymphoma in the Pre-Highly Active Antiretroviral Therapy (HAART) and HAART Eras. J. Clin. Oncol. 2005, 23, 4430-4438. [CrossRef] [PubMed]

13. Wiggill, T.M.; Mantina, H.; Willem, P.; Perner, Y.; Stevens, W. Changing Pattern of Lymphoma Subgroups at a Tertiary Academic Complex in a High-Prevalence HIV Setting; A South African Perspective. J. Acquir. Immune Defic. Syndr. 2011, 56, 460-466. [CrossRef]

14. Alves de Souza Rios, L.; Mapekula, L.; Mdletshe, N.; Chetty, D.; Mowla, S. HIV-1 Transactivator of Transcription (Tat) Co-operates With AP-1 Factors to Enhance c-MYC Transcription. Front. Cell Dev. Biol. 2021, 9, 693706. [CrossRef] [PubMed]

15. Mdletshe, N.; Nel, A.; Shires, K.; Mowla, S. HIV Nef enhances the expression of oncogenic c-MYC and activation-induced cytidine deaminase in Burkitt lymphoma cells, promoting genomic instability. Infect. Agents Cancer 2020, 15, 37. [CrossRef]

16. Sall, F.B.; El Amine, R.; Markozashvili, D.; Tsfasman, T.; Oksenhendler, E.; Lipinski, M.; Vassetzky, Y.; Germini, D. HIV-1 Tat protein induces aberrant activation of AICDA in human B-lymphocytes from peripheral blood. J. Cell Physiol. 2019, 234, 15678-15685. [CrossRef] [PubMed]

17. Germini, D.; Tsfasman, T.; Klibi, M.; El-Amine, R.; Pichugin, A.; Iarovaia, O.V.; Bilhou-Nabera, C.; Subra, F.; Bou Saada, Y.; Sukhanova, A.; et al. HIV Tat induces a prolonged MYC relocalization next to IGH in circulating B-cells. Leukemia 2017, 31, 2515-2522. [CrossRef]

18. Dolcetti, R.; Giagulli, C.; He, W.; Selleri, M.; Caccuri, F.; Eyzaguirre, L.M.; Mazzuca, P.; Corbellini, S.; Campilongo, F.; Marsico, S.; et al. Role of HIV-1 matrix protein p17 variants in lymphoma pathogenesis. Proc. Natl. Acad. Sci. USA 2015, 112, 14331-14336. [CrossRef]

19. Mapekula, L.; Ramorola, B.R.; Goolam Hoosen, T.; Mowla, S. The interplay between viruses \& host microRNAs in cancer-An emerging role for HIV in oncogenesis. Crit. Rev. Oncol. Hematol. 2019, 137, 108-114. [CrossRef]

20. Moir, S.; Malaspina, A.; Li, Y.; Chun, T.-W.; Lowe, T.; Adelsberger, J.; Baseler, M.; Ehler, L.A.; Liu, S.; Davey, R.T.; et al. B Cells of HIV-1-Infected Patients Bind Virions through Cd21-Complement Interactions and Transmit Infectious Virus to Activated T Cells. J. Exp. Med. 2000, 192, 637-646. [CrossRef]

21. Hanna, J.; Hossain, G.S.; Kocerha, J. The Potential for microRNA Therapeutics and Clinical Research. Front. Genet. 2019, 10, 478. [CrossRef]

22. Humphries, B.; Yang, C. The microRNA-200 family: Small molecules with novel roles in cancer development, progression and therapy. Oncotarget 2015, 6, 6472-6498. [CrossRef]

23. Tamagawa, S.; Beder, L.B.; Hotomi, M.; Gunduz, M.; Yata, K.; Grenman, R.; Yamanaka, N. Role of miR-200c/miR-141 in the regulation of epithelial-mesenchymal transition and migration in head and neck squamous cell carcinoma. Int. J. Mol. Med. 2014, 33, 879-886. [CrossRef] [PubMed]

24. Rossio, J.L.; Esser, M.T.; Suryanarayana, K.; Schneider, D.K.; Bess, J.W.; Vasquez, G.M.; Wiltrout, T.A.; Chertova, E.; Grimes, M.K.; Sattentau, Q.; et al. Inactivation of Human Immunodeficiency Virus Type 1 infectivity with preservation of conformational and functional integrity of virion surface proteins. J. Virol. 1998, 72, 7992-8001. [CrossRef] [PubMed]

25. Agarwal, V.; Bell, G.W.; Nam, J.-W.; Bartel, D.P. Predicting effective microRNA target sites in mammalian mRNAs. eLife 2015, 4, e05005. [CrossRef] [PubMed]

26. Karagkouni, D.; Paraskevopoulou, M.D.; Chatzopoulos, S.; Vlachos, I.S.; Tastsoglou, S.; Kanellos, I.; Papadimitriou, D.; Kavakiotis, I.; Maniou, S.; Skoufos, G.; et al. DIANA-TarBase v8: A decade-long collection of experimentally supported miRNA-gene interactions. Nucleic Acids Res. 2018, 46, D239-D245. [CrossRef] [PubMed] 
27. Chen, Y.; Wang, X. miRDB: An online database for prediction of functional microRNA targets. Nucleic Acids Res. 2020, 48, D127-D131. [CrossRef]

28. Liu, W.; Wang, X. Prediction of functional microRNA targets by integrative modeling of microRNA binding and target expression data. Genome Biol. 2019, 20, 18. [CrossRef]

29. Heberle, H.; Meirelles, G.V.; Da Silva, F.R.; Telles, G.P.; Minghim, R. InteractiVenn: A web-based tool for the analysis of sets through Venn diagrams. BMC Bioinform. 2015, 16, 169. [CrossRef]

30. Dennis, G.; Sherman, B.T.; Hosack, D.A.; Yang, J.; Gao, W.; Lane, H.C.; Lempicki, R.A. DAVID: Database for Annotation, Visualization, and Integrated Discovery. Genome Biol. 2003, 4, R60. [CrossRef]

31. Dvinge, H.; Bertone, P. HTqPCR: High-throughput analysis and visualization of quantitative real-time PCR data in R. Bioinformatics 2009, 25, 3325-3326. [CrossRef] [PubMed]

32. Mestdagh, P.; Van Vlierberghe, P.; De Weer, A.; Muth, D.; Westermann, F.; Speleman, F.; Vandesompele, J. A novel and universal method for microRNA RT-qPCR data normalization. Genome Biol. 2009, 10, R64. [CrossRef]

33. Lenze, D.; Leoncini, L.; Hummel, M.; Volinia, S.; Liu, C.G.; Amato, T.; De Falco, G.; Githanga, J.; Horn, H.; Nyagol, J.; et al. The different epidemiologic subtypes of Burkitt lymphoma share a homogenous micro RNA profile distinct from diffuse large B-cell lymphoma. Leukemia 2011, 25, 1869-1876. [CrossRef] [PubMed]

34. Le Sage, C.; Nagel, R.; Egan, D.A.; Schrier, M.; Mesman, E.; Mangiola, A.; Anile, C.; Maira, G.; Mercatelli, N.; Ciafrè, S.A.; et al. Regulation of the p27Kip1 tumor suppressor by miR-221 and miR-222 promotes cancer cell proliferation. EMBO J. 2007, 26, 3699-3708. [CrossRef] [PubMed]

35. Lim, E.L.; Trinh, D.L.; Scott, D.W.; Chu, A.; Krzywinski, M.; Zhao, Y.; Robertson, A.G.; Mungall, A.J.; Schein, J.; Boyle, M.; et al. Comprehensive miRNA sequence analysis reveals survival differences in diffuse large B-cell lymphoma patients. Genome Biol. 2015, 16, 18. [CrossRef]

36. Park, S.M.; Gaur, A.B.; Lengyel, E.; Peter, M.E. The miR-200 family determines the epithelial phenotype of cancer cells by targeting the E-cadherin repressors ZEB1 and ZEB2. Genes Dev. 2008, 22, 894-907. [CrossRef]

37. Berglund, M.; Hedstrom, G.; Amini, R.M.; Enblad, G.; Thunberg, U. High expression of microRNA-200c predicts poor clinical outcome in diffuse large B-cell lymphoma. Oncol. Rep. 2013, 29, 720-724. [CrossRef]

38. Zheng, Z.; Li, X.; Zhu, Y.; Gu, W.; Xie, X.; Jiang, J. Prognostic Significance of MiRNA in Patients with Diffuse Large B-Cell Lymphoma: A Meta-Analysis. Cell. Physiol. Biochem. 2016, 39, 1891-1904. [CrossRef]

39. Zhou, X.; Wang, Y.; Shan, B.; Han, J.; Zhu, H.; Lv, Y.; Fan, X.; Sang, M.; Liu, X.-D.; Liu, W. The downregulation of miR-200c/141 promotes ZEB1/2 expression and gastric cancer progression. Med. Oncol. 2015, 32, 428. [CrossRef]

40. Zhu, W.; Xu, H.; Zhu, D.; Zhi, H.; Wang, T.; Wang, J.; Jiang, B.; Shu, Y.; Liu, P. miR-200bc/429 cluster modulates multidrug resistance of human cancer cell lines by targeting BCL2 and XIAP. Cancer Chemother. Pharmacol. 2012, 69, 723-731. [CrossRef]

41. Cochrane, D.R.; Howe, E.N.; Spoelstra, N.S.; Richer, J.K. Loss of miR-200c: A Marker of Aggressiveness and Chemoresistance in Female Reproductive Cancers. J. Oncol. 2010, 2010, 821717. [CrossRef]

42. Cochrane, D.R.; Spoelstra, N.S.; Howe, E.N.; Nordeen, S.K.; Richer, J.K. MicroRNA-200c mitigates invasiveness and restores sensitivity to microtubule-targeting chemotherapeutic agents. Mol. Cancer Ther. 2009, 8, 1055-1066. [CrossRef] [PubMed]

43. Kopp, F.; Wagner, E.; Roidl, A. The proto-oncogene KRAS is targeted by miR200c. Oncotarget 2014, 5, 185-195. [CrossRef] [PubMed]

44. Qiu, M.; Liang, Z.; Chen, L.; Tan, G.; Liu, L.; Wang, K.; Chen, H.; Liu, J. MicroRNA-200c suppresses cell growth and metastasis by targeting Bmi-1 and E2F3 in renal cancer cells. Exp. Ther. Med. 2017, 13, 1329-1336. [CrossRef] [PubMed]

45. Liu, S.; Tetzlaff, M.T.; Cui, R.; Xu, X. miR-200c inhibits melanoma progression and drug resistance through down-regulation of BMI-1. Am. J. Pathol. 2012, 181, 1823-1835. [CrossRef]

46. Howe, E.N.; Cochrane, D.R.; Richer, J.K. Targets of miR-200c mediate suppression of cell motility and anoikis resistance. Breast Cancer Res. 2011, 13, R45. [CrossRef]

47. Zhang, H.; Sun, Z.; Li, Y.; Fan, D.; Jiang, H. MicroRNA-200c binding to FN1 suppresses the proliferation, migration and invasion of gastric cancer cells. Biomed. Pharmacother. 2017, 88, 285-292. [CrossRef]

48. Panda, H.; Pelakh, L.; Chuang, T.-D.; Luo, X.; Bukulmez, O.; Chegini, N. Endometrial miR-200c is Altered During Transformation into Cancerous States and Targets the Expression of ZEBs, VEGFA, FLT1, IKK $\beta$, KLF9, and FBLN5. Reprod. Sci. 2012, 19, 786-796. [CrossRef] [PubMed]

49. Title, A.C.; Hong, S.-J.; Pires, N.D.; Hasenöhrl, L.; Godbersen, S.; Stokar-Regenscheit, N.; Bartel, D.P.; Stoffel, M. Genetic dissection of the miR-200-Zeb1 axis reveals its importance in tumor differentiation and invasion. Nat. Commun. 2018, 9, 4671. [CrossRef]

50. Zhang, Y.; Xu, L.; Li, A.; Han, X. The roles of ZEB1 in tumorigenic progression and epigenetic modifications. Biomed. Pharm. 2019, 110, 400-408. [CrossRef]

51. Shiels, M.S.; Engels, E.A. Evolving epidemiology of HIV-associated malignancies. Curr. Opin. HIV AIDS 2017, 12, 6-11. [CrossRef] [PubMed]

52. Isaguliants, M.; Bayurova, E.; Avdoshina, D.; Kondrashova, A.; Chiodi, F.; Palefsky, J.M. Oncogenic Effects of HIV-1 Proteins, Mechanisms Behind. Cancers 2021, 13, 305. [CrossRef] [PubMed]

53. Martorelli, D.; Muraro, E.; Mastorci, K.; Dal Col, J.; Fae, D.A.; Furlan, C.; Giagulli, C.; Caccuri, F.; Rusnati, M.; Fiorentini, S.; et al. A natural HIV p17 protein variant up-regulates the LMP-1 EBV oncoprotein and promotes the growth of EBV-infected B-lymphocytes: Implications for EBV-driven lymphomagenesis in the HIV setting. Int. J. Cancer 2015, 137, 1374-1385. [CrossRef] 
54. Modai, S.; Farberov, L.; Herzig, E.; Isakov, O.; Hizi, A.; Shomron, N. HIV-1 infection increases microRNAs that inhibit Dicer1, HRB and HIV-EP2, thereby reducing viral replication. PLOS ONE 2019, 14, e0211111. [CrossRef] [PubMed]

55. Yao, S.; Hu, M.; Hao, T.; Li, W.; Xue, X.; Xue, M.; Zhu, X.; Zhou, F.; Qin, D.; Yan, Q.; et al. MiRNA-891a-5p mediates HIV-1 Tat and KSHV Orf-K1 synergistic induction of angiogenesis by activating NF-kB signaling. Nucleic Acids Res. 2015, 43, 9362-9378. [CrossRef] [PubMed]

56. Luzzi, A.; Morettini, F.; Gazaneo, S.; Mundo, L.; Onnis, A.; Mannucci, S.; Rogena, E.A.; Bellan, C.; Leoncini, L.; De Falco, G. HIV-1 Tat induces DNMT over-expression through microRNA dysregulation in HIV-related non Hodgkin lymphomas. Infect. Agents Cancer 2014, 9, 41. [CrossRef] [PubMed]

57. Manavalan, T.T.; Teng, Y.; Litchfield, L.M.; Muluhngwi, P.; Al-Rayyan, N.; Klinge, C.M. Reduced Expression of miR-200 Family Members Contributes to Antiestrogen Resistance in LY2 Human Breast Cancer Cells. PLoS ONE 2013, 8, e62334. [CrossRef]

58. Peter, M.E. Let-7 and miR-200 microRNAs: Guardians against pluripotency and cancer progression. Cell Cycle 2009, 8, 843-852. [CrossRef]

59. Ibrahim, F.F.; Jamal, R.; Syafruddin, S.E.; Mutalib, N.S.A.; Saidin, S.; MdZin, R.R.; Hossain Mollah, M.M.; Mokhtar, N.M. microRNA-200c and microRNA-31 regulate proliferation, colony formation, migration and invasion in serous ovarian cancer. J. Ovarian Res. 2015, 8, 56. [CrossRef]

60. Chuang, T.D.; Panda, H.; Luo, X.; Chegini, N. miR-200c is aberrantly expressed in leiomyomas in an ethnic-dependent manner and targets ZEBs, VEGFA, TIMP2, and FBLN5. Endocr. Relat. Cancer 2012, 19, 541-556. [CrossRef]

61. Valencia-Sanchez, M.A. Control of translation and mRNA degradation by miRNAs and siRNAs. Genes Dev. 2006, 20, 515-524. [CrossRef]

62. Caramel, J.; Ligier, M.; Puisieux, A. Pleiotropic roles of ZEB1 in cancer. Cancer Res. 2018, 78, 30-35. [CrossRef] [PubMed]

63. Brabletz, S.; Brabletz, T. The ZEB/miR-200 feedback loop-a motor of cellular plasticity in development and cancer? EMBO Rep. 2010, 11, 670-677. [CrossRef] [PubMed]

64. Burk, U.; Schubert, J.; Wellner, U.; Schmalhofer, O.; Vincan, E.; Spaderna, S.; Brabletz, T. A reciprocal repression between ZEB1 and members of the miR-200 family promotes EMT and invasion in cancer cells. EMBO Rep. 2008, 9, 582-589. [CrossRef]

65. Hill, L.; Browne, G.; Tulchinsky, E. ZEB/miR-200 feedback loop: At the crossroads of signal transduction in cancer. Int. J. Cancer 2013, 132, 745-754. [CrossRef]

66. Tahtamouni, L.; Ahram, M.; Koblinski, J.; Rolfo, C. Molecular regulaion of cancer cell migration, invasion and metastasis. Anal. Cell Pathol. 2019, 2019, 1356508. [CrossRef]

67. Yang, S.; Zhang, X.; Sun, Y.; Shi, J.; Jiang, D.; Wang, J.; Liu, Y.; Hu, C.; Zhang, X.; Pan, J.; et al. MicroRNA-362-3p Inhibits Migration and Invasion via Targeting BCAP31 in Cervical Cancer. Front. Mol. Biosci. 2020, 9, 107. [CrossRef] [PubMed]

68. Shen, X.; Jiang, H.; Chen, Z.; Lu, B.; Zhu, Y.; Mao, J.; Chai, K.; Chen, W. MicroRNA-145 Inhibits Cell Migration and Invasion in Colorectal Cancer by Targeting TWIST. Onco Targets Ther. 2019, 10, 10799-10809. [CrossRef] 